\title{
KOMPETENSI KEAGAMAAN MAHASISWA PRODI PAI FAKULTAS TARBIYAH DAN KEGURUAN UIN SUNAN AMPEL SURABAYA (Analisis Perbandingan Penerimaan Jalur SPAN, UM PTKIN dan Jalur Mandiri Tahun 2016)
}

\author{
Sutikno \\ (UIN Sunan Ampel Surabaya)
}

\begin{abstract}
Abstrak:
Realita menunjukkan bahwa ada sebagian mahasiswa Prodi PAI FTK UIN Sunan Ampel Surabaya penguasaan kompetensi keagamaannya kurang memadai, terutama dalam baca tulis al-Qur'ān dan al-Ḥadith, baik yang diterima melalui jalur SPAN, UM PTKIN maupun jalur Mandiri. Dengan demikian, timbul kekhawatiran atas kesenjangan antara masukan dan harapan keluaran Prodi PAI yang mencetak calon guru PAI yang profesional. Penelitian deskriptif kuantitatif ini menggunakan pendekatan fenomenologi evaluatif. Hasil analisis menggunakan One Way Anova menunjukkan $F_{\text {hitung }}=44,88$ dan uji $\mathrm{T}$ dengan $t_{\text {hitung }}=9,433$. Apabila $F_{\text {hitung }}=$ 44,88 dikonfirmasi dengan nilai $\mathrm{F}_{\text {tabel, }}$ baik menggunakan taraf signifikansi $5 \%$ dan $1 \%$, maka $F_{\text {hitung }}>F_{\text {tabel }}(3,44<44,88>4,88)$. Apabila $t_{\text {hitung }}=9,433$ dikonfirmasi dengan nilai $t_{\text {tabel, }}$, baik menggunakan taraf signifikansi $5 \%$ dan $1 \%$, maka $t_{\text {hitung }}>t_{\text {tabel }}(1,665<9,433>2,376)$, menunjukkan ada persamaan dan perbedaan yang signifikan kompetensi keagamaan mahasiswa Prodi PAI FTK UINSA, baik jalur SPAN, UM PTKIN maupun Mandiri. Persamaannya, pertama nilai rata-rata kompetensi keagamaan pada masing-masing jalur penerimaan terletak pada nilai A- s/d A (9,18 s/d 10,49); kedua, Studi Hadith sebagai mata kuliah keagamaan dengan nilai terendah. Perbedaannya, nilai tertinggi jalur SPAN dan UM PTKIN ditempati oleh Aqidah Ilmu Kalam, sedangkan nilai tertinggi pada jalur mandiri ditempati oleh Fiqih Ibadah.
\end{abstract}

Kata Kunci: Kompetensi Keagamaan; SPAN; UM PTKIN; Jalur Mandiri. 


\begin{abstract}
:
It is the fact that mastery of Islamic Religious Subjects by some new students at Islamic Education Department of UIN Sunan Ampel Surabaya is not yet satisfying, especially in reading al-Qur'an and al-Hadith, by those admitted through SPAN, UM PTKIN or Jalur Mandiri (institutional test). Thus, there is an apprehension about quality disparity between the input and expected output of Islamic education teacher training program to result in professional teachers. This descriptive quantitative research uses an evaluative phenomenology approach. Based on the results of the analysis using One Way Anova, obtained F-count $=44,88$ and T-test, which yield $\mathrm{t}$-count $=9,433$. If $\mathrm{F}$-count $=44.88$ is confirmed against F-table score, using both the $5 \%$ and $1 \%$ significance levels, then F-count $>$ F-table $(3.44$ $<44,88>4.88$ ). If $t$-count $=9,433$ is confirmed with t-table value, using $5 \%$ and $1 \%$ significance level, then t-count > t-table $(1,665<9,433>2,376)$, shows there are similarities and significant differences of religious competence of students of Islamic education teacher training of UINSA admitted through SPAN, UM PTKIN and Jalur Mandiri. The similarities is, first, the average score of religious competence in every entry test model lies in the A- and A (9.18 to 10.49); second, in average students experienced Hadith studies in the training process with as the lowest grade. The difference is that the students admitted through the SPAN and UM PTKIN modes achieved high score in Aqidah Ilmu Kalam during the training, while those coming from Jalur Mandiri are strong in Fiqh Ibadah (Fiqih 1).
\end{abstract}

\title{
Keywords: Religious Competence; SPAN; UM PTKIN; Jalur Mandiri.
}

\section{A. Pendahuluan}

Salah satu harapan terbesar Universitas Islam Negeri Sunan Ampel Surabaya adalah menjadikan kultur akademik yang berkomitmen pada upaya Building Character Qualities; For The Smart, Pious and Honorable Nation. Maka, penerimaan mahasiswa dari berbagai jalur serta penataan sistem akademik menjadi keharusan dengan menyesuaikan aturan yang dibutuhkan di Universitas Islam Negeri Sunan Ampel Surabaya. Seleksi mahasiswa dimaksudkan untuk penguatan Sumber Daya Manusia yang dimulai dari awal proses mahasiswa. Di sisi lain, seleksi tersebut diharapkan membentuk pola pikir atau pandangan secara menyeluruh dengan kesadaran individu pada semangat integrasi keilmuan yang berbasis agama dan umum.

Namun, harapan baru melahirkan tantangan yang baru pula. Misalnya, tantangan yang dimaksud adalah menjaga nuansa keagamaan ini tetap terjaga 
sebagai simbol Universitas Islam Negeri. Pasalnya, mereka yang berminat masuk ke Universitas Islam Negeri Sunan Ampel Surabaya (UINSA) terfragmentasi dalam jalur-jalur penerimaan mahasiswa. Maka pertemuan mahasiswa dari berbagai jalur seleksi akan berdampak pada penyikapan keduanya dalam lingkungan kampus Universitas Islam Negeri Sunan Ampel Surabaya (UINSA) yang mengalami perubahan dengan karakter keislaman yang harus dipertahankan. Oleh sebab itu, cita-cita mengawal terwujudnya output Universitas Islam Negeri Sunan Ampel Surabaya (UINSA) sebagaimana diinginkan, tidak cukup hanya mengandalkan pada kecerdasan kognisi semata, tetapi perlu secara serius menjadikan UINSA sebagai institusi pembentukan karakter mahasiswa yang memiliki pemahaman keagaman yang kuat. Mengenai seleksi mahasiswa, UIN Sunan Ampel dalam memfasilitasi peminatnya telah membuka berbagai jalur penerimaan calon mahasiswa baru bagi para peminat yang ingin diterima sebagai mahasiswa Prodi PAI. Jalur penerimaan yang dimaksud terdiri dari SNMPTN, SPAN-PTKIN, SBMPTN, UM PTKIN TKIN atau juga dikenal sebagai UM-PTKIN, Bidik Misi dan jalur Mandiri.

Sebagai Prodi yang termasuk dalam kategori keagamaan dengan peminat yang sangat banyak, dapat dilihat dari jumlah peminat yang mendaftar yang memilh Prodi PAI, yaitu pada tahun 2016 sebanyak 4206 dan pada tahun 2017 sebanyak 4104, menunjukkan bahwa Prodi PAI FTK UIN Sunan Ampel sangat diminati, sementara yang diterima hanya sekitar 120 s/d 140 mahasiswa per tahun 1,Prodi PAI meniscayakan penguasaan kompetensi keagamaan bagi peminatnya. Kompetensi keagamaan berkaitan dengan pemahaman pengetahuan ajaran agama sekaligus pengamalan dalam kehidupan sehari-hari. ${ }^{2}$

Salah satu kompetensi keagamaan yang harus dikuasai oleh calon mahasiswa PAI yaitu kompetensi baca tulis al-Qur'ān dan al-Hadith, karena keduanya merupakan sumber utama dan dasar agama Islam. Penguasaan kompetensi ini pasti berbeda pada setiap calon mahasiswa. Perbedaan ini tentunya disebabkan oleh pengalaman belajar pada jenjang pendidikan sebelumnya. Perbedaan kompetensi mahasiswa Prodi PAI dalam bidang tersebut secara umum dapat diklasifikasikan menjadi tiga, yaitu kompeten, cukup kompeten dan kurang kompeten. Dengan demikian, secara realita terdapat sebagian mahasiswa PAI yang kurang kompeten dalam baca tulis al-Qur'ān dan al-Hadith. ${ }^{3}$

\footnotetext{
${ }^{1}$ Dokumen bagian Akademik dan Kemahasiswaan FTK UIN Sunan Ampel Surabaya.

2 Choirul Fuad Yusuf, Inovasi Pendidikan Agama dan Keagamaan (Jakarta: Kemenag RI, 2006), 84.

${ }^{3}$ Pengalaman Peneliti pada waktu menjadi penguji skripsi, mahasiswa tidak dapat menulis huruf Arab. Demikian pula pendapat dosen mata kuliah Studi Hadith, Bapak Drs. M. Nawawi,
} 
Dengan kenyataan demikian, maka timbul kesenjangan antara realita dengan hrapan output Prodi PAI yang akan dicetak, yaitu melahirkan guru PAI yang profesional. Keprofesionalan guru PAI sendiri dapat diidentifikasi dari kemampuan guru dalam mengikuti (meng-update) pengetahuan dan keterampilannya sesuai dengan perkembangan khazanah keilmuwan. ${ }^{4}$ Bahkan, dalam Peraturan Pemerintah (PP) Republik Indonesia No. 19 Tahun 2005 tentang Standar Nasional Pendidikan Bab VI Pasal 28 ayat (1) menyatakan bahwa "pendidik harus memiliki kualifikasi akademik dan kompetensi sebagai agen pembelajaran, sehat jasmani dan rohani, serta memiliki kemampuan untuk merealisasikan tujuan pendidikan nasional." ${ }^{5}$

Kompetensi baca al-Qur'ān dan al-Hadith termasuk sebagian dari nilai keprofesionalan guru PAI. Kompetensi tersebut merupakan kompetensi dasar yang wajib dimiliki oleh seorang guru PAI. Al-Qur'ān dan al-Hadith sendiri bertindak sebagai dasar sekaligus sumber pembelajaran agama Islam yang harus dipelajari oleh guru beserta peserta didiknya. ${ }^{6}$ Oleh karena itu, keduanya dijadikan salah satu aspek dalam materi PAI, yaitu al-Qur'ān dan al-Ḥadith.

Diberikannya pembelajaran al-Qur'ān dan al-Ḥadith bertujuan untuk memberikan pendidikan pada peserta didik dalam memahami dan mencintai alQur'ān dan al-Hadith sebagai sumber ajaran Islam sehingga mengamalkan isi kandungannya dalam kehidipan sehari-hari. ${ }^{7}$ Dengan demikian, harapan dari pembelajaran tersebut terbentuk peserta didik yang gemar membaca dengan benar serta mempelajarinya, memahami, meyakini kebenarannya dan mengamalkan ajaran-ajaran dan nilai-nilai yang terkandung di dalamnya sebagai petunjuk dan pedoman dalam seluruh aspek kehidupannya. ${ }^{8}$

Dari realita yang tergambar, yaitu ada sebagian mahasiswa Prodi PAI yang kurang kompeten dalam bidang baca tulis al-Qur'ān dan al-Ḥadith padahal peminat untuk menjadi mahasiswa PAI selalu banyak setiap tahunnya dan tuntutan Prodi PAI yang harus mencetak seorang guru PAI yang profesional, maka diperlukan suatu analisis dini. Analisis ini memiliki tujuan untuk mengidentifikasi sejauh mana penguasaan kompetensi baca tulis al-Qur'ān dan

M.Ag, menyampaikan ada mahasiswa yang tidak dapat menulis Hadith. M. Nawawi, Wawancara, Surabaya, 20 Agustus 2017.

4 Syaiful Sagala, Kemampuan Profesional Guru dan Tenaga Kependidikan (Bandung: Alfabeta, 2011), 29.

${ }^{5}$ Kemenag RI, Standar Nasional Pendidikan Agama Islam (Jakarta: PAIS, 2011), 121.

${ }^{6}$ M. Arifin, Ilmu Pendidikan Islam (Jakarta: Bina Aksara,1994), 47.

7 Departemen Agama RI, Pedoman Khusus Al-Qur'an-Hadis (Jakarta: Dirjen Bagais, 2004), 4.

8 Ali Mudlofir, Aplikasi Pengembangan Kurikulum Tingkat Satuan Pendidikan dan Bahan Ajar dalam Pendidikan Islam (Jakarta: Rajawali Pers, 2011), 47. 
al-Ḥadith yang telah dikuasai oleh mahasiswa PAI, yang diterima melalui berbagai jalur penerimaan mahasiswa baru di UIN Sunan Ampel Surabaya.

Berdasarkan dari penjabaran di atas, maka merupakan suatu alasan yang sangat mendasar dan logis apabila peneliti akan membahas permasalahan tersebut dalam penelitian yang berjudul "Kompetensi Keagamaan Mahasiswa Prodi PAI Fakultas Tarbiyah dan Keguruan UIN Sunan Ampel Surabaya (Analisis Perbandingan Penerimaan Jalur SPAN, UMPTKIN dan Jalur Mandiri Tahun 2016". Semoga penelitian ini dapat bermanfaat bagi Prodi PAI Fakultas Tarbiyah dan Keguruan UIN Sunan Ampel Surabaya sebagai bahan evaluasi proses perkuliahan yang telah dilakukan.

\section{B. Perkembangan dan Kompetensi Keagamaan Mahasiswa}

Dalam hal pemahaman keagamaan pada anak didik, Zakiah Darajat, berpendapat bahwa ada beberapa hal yang harus diperhatikan, di antaranya: ${ }^{9}$ Pertama, perkembangan agama. Perkembangan agama pada anak sangat ditentukan oleh pendidikan dan pengalaman agama yang dilaluinya, terutama pada masa-masa pertumbuhan pertama (masa anak) dari umur 0-12 tahun. Anak mulai mengenal Tuhan melalui orang tua dan lingkungan keluarganya. Kata-kata, sikap, tindakan dan perbuatan orang tua, sangat mempengaruhi perkembangan agama pada anak. Anak menerima apa saja yang dikatakan oleh orang tua kepadanya. Dia belum mempunyai kemampuan untuk memikirkan kata itu. Anak yang merasakan adanya hubungan hangat dengan orang tua, merasa ia disayangi dan dilindungi serta mendapat perlakuan baik, biasanya akan mudah menerima dan mengikuti kebiasaan orang tuanya dan selanjutnya cenderung kepada agama. Oleh karena itu pertumbuhan dan perkembangan anak antara satu dengan yang lain tidak sama, karena tergantung kepada orang tuanya.

Ketika anak sudah berada di sekolah, pendidik mempunyai peranan penting untuk menanamkan sikap keagamaan kepada anak didik. ${ }^{10}$ Dengan perbedaan sikap keagamaan yang dimiliki anak dari rumah maka pendidik harus memiliki kepandaian dan kebijaksanaan yang dapat memperbaiki dan mendekatkan semua anak ke arah perkembangan agama yang sehat. tentu saja

\footnotetext{
9 Zakiah Darajat, Ilmu Jiwa Agama (Jakarta: Bulan Bintang, 2005), 69-77.

${ }^{10}$ Hal yang perlu disadari dan diperhatikan oleh pendidik adalah anak-anak pada umur sekolah dasar sedang dalam pertumbuhan kecerdasan cepat. Khayal dan fantasinya sedang subur dan kemampuan untuk berpikir logis sedang dalam pertumbuhan. Anak yang berumur 12 tahun, belum mampu berpikir abstrak (maknawi). Oleh karena itu, pendidik hendaknya mendekatkan ajaran agama itu ke dalam kehidupan sehari-hari. Di sinilah letak pentingnya pembiasaan-pembiasaan dalam pendidikan agama Islam. Lihat Darajat, Ilmu Jiwa Agama, 69-77.
} 
pekerjaan itu tidak mudah, oleh karena itu seorang pendidik harus memiliki bekal yang cukup, antara lain: (1) Pribadi pendidik agama itu sendiri, dia harus memiliki pribadi yang dapat dijadikan suri tauladan dari pendidikan agama yang dibawakannya kepada anak; (2) Pengertian dan kemampuannya untuk memahami perkembangan jiwa anak serta perbedaan perorangan antara seorang anak dan lainnya; (3) Pendidik harus menguasai ilmu-ilmu pendidikan seperti didakti, metode, alat pembelajaran dan sebagainya.

Kedua, pembiasaan pendidikan agama. Hendaknya setiap pendidik menyadari bahwa dalam pembinaan pribadi anak sangat diperlukan pembiasaan-pembiasaan dan latihan-latihan yang cocok dan sesuai dengan perkembangan jiwanya. Karena pembiasaan dan latihan tersebut akan membentuk sikap tertentu pada anak, yang lambat laun sikap itu bertambah jelas dan kuat, akhirnya tidak tergoyahkan lagi, karena telah masuk menjadi bagian dari pribadinya. Oleh karena itu, latihan-latihan keagamaan yang menyangkut ibadah seperti sholat berjamaah, doa, membaca Al- Qur'an, harus dibiasakan sejak kecil baik di sekolah maupun di rumah, sehingga dengan sendirinya akan terdorong untuk melakukannya. Selain itu, latihan keagamaan yang menyangkut akhlak dan ibadah sosial yang sesuai dengan ajaran agama, hendaknya disampaikan pada anak dengan memberikan contoh oleh pendidik dan orang tua. Maka dari itu, pembiasaan dalam pendidikan anak sangat penting, terutama dalam pembentukan pribadi, akhlak, dan agama pada umunya. Karena pembiasaan-pembiasaan agama itu akan memasukkan unsur -unsur positif dalam pribadi anak yang sedang bertumbuh.

Ketika seorang anak didik menginjak masa remaja dan dewasa (terutama masa mahasiswa), maka sikap keagamaannya pada dasarnya, ada dua yaitu: 11 Pertama, sikap individu terhadap diri sendiri. Sebagai individu, kita harus menyayangi diri kita sebelum kita menyayangi orang lain. Oleh karena itu, sebagai mahasiswa harus berperilaku terpuji terhadap diri sendiri yakni; menjaga kesehatan badan dengan berolah raga, menjaga kebersihan badan dan pakaian, serta mengatur hidup, selalu berbuat baik, dan selalu menyayangi apa yang ada di sekitar serta beribadah kepada Allah Swt. agar apa yang kita citacitakan tercapai. Kedua, sikap sosial. Sikap sosial dibatasi pada sikap mahasiswa dengan orang tua dan sikap siswa terhadap guru dan sesama teman. Adapun bentuk sikap sosial mahasiswa antara lain: (1) Sikap mahasiswa terhadap orang tua. Orang tua merupakan orang yang menduduki penting dalam sebuah keluarga, karena orang tua adalah orang yang mengasuh kita dari kecil, memberi kasih sayang, mensekolahkan kita. Sehingga kita senantiasa berbakti kepada

${ }^{11}$ Muhammad Ali Al- Hasyimi, Sosok Pria Muslim (Bandung: Trigenda Karya, 1996), 73. 
orang tua, dengan mendoakannya, berbuat baik kepada orang tua, bertingkah laku sopan, bertutur kata lembut, menghormati mereka dan tidak menyakiti hati orang tua. (2) Sikap mahasiswa terhadap dosen/guru. Dosen/guru adalah pengganti orang tua. Dosen/guru yang mendidik serta membimbing mahasiswa di sebuah institusi pendidikan untuk menuju pribadi yang berkarakter. Oleh karena itu, sebagai mahasiswa wajib menghormati dosen/guru, bertingkah laku sopan, dan selalu mentaati perintahnya selama tidak menyimpang dalam norma agama. Demikianlah beberapa sikap mahasiswa terhadap dosen/guru yang harus selalu diperhatikan, dan inilah moral yang baik dalam tuntunan ajaran Islam bagi mahasiswa. (3) Sikap mahasiswa terhadap sesama mahasiswa. Sebagai mahasiswa, hendaknya memiliki sifat-sifat akhlāq al karimah terhadap orang lain seperti saling menolong, saling membantu, dan saling menasehati, berbuat baik kepada orang lain sebagaimana agama Islam menganjurkan. Seseorang yang berakhlak mulia akan selalu disukai orang lain, disenangi oleh teman sebaya dan masyarakat lingkungannya.

Terkait agama, perlu dipahami bahwa agama suatu sikap hidup yang membuat orang mengatasi kesulitan sebagai manusia dengan memberikan jawaban yang memberi kepuasan spiritual pada pertanyaan mendasar tentang teka-teki alam semesta dan perasaan manusia didalamnya dengan memberikan ajaran praktis untuk hidup dialam semesta. ${ }^{12}$ Kompetensi keagamaan merupakan kemampuan atau pemahaman yang ada dalam diri seseorang yang mendorongnya bertingkah laku sesuai dengan kadar ketaatannya pada agama. Sikap keagamaan terbentuk karena adanya konsistensi antara kepercayaan terhadap agama sebagai komponen kognitif, pemahaman dan penghayatan terhadap agama sebgai komponen afektif dan perilaku terhadap agama sebagai komponen konatif.

Tujuan kompetensi keagamaan yakni untuk beribadah kepada Allah Swt untuk mencapai kebahagiaan akhirat. Namun, tujuan kompetensi keagamaan tersebut direalisasikan dalam bentuk hubungan perilaku seseorang kepada orang lain dalam kehidupan sehari-hari. Adapun di antara tujuan kompetensi keagamaan antara lain: Pertama, beribadah kepada Allah SWT. Sebagaimana dalam firman-Nya dalam Surat al-A'laa: 14-17:

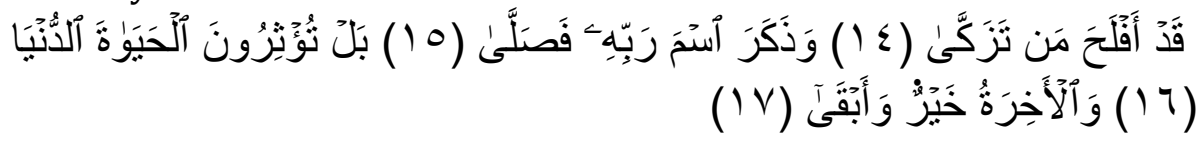

12 Musa Asy'arie, Agama, Kebudayaan Dalam Pembangunan Menyonsong Era Industrialisasi (Yogyakarta: IAIN Kalijaga Press, 1998), 25.

Jurnal Pendidikan Agama Islam (Journal of Islamic Education Studies)

Volume 5 Nomor 2 (2017)

ISSN(p) 2089-1946\& ISSN(e) 2527-4511

Hal. 250 - 263 
"Sesungguhnya beruntunglah orang yang membersihkan diri (dengan beriman). Dan Dia ingat nama Tuhannya, lalu Dia sembahyang. Tetapi kamu (orang-orang kafir) memilih kehidupan duniawi. Sedang kehidupan akhirat adalah lebih baik dan lebih kekal."

Kedua, membentuk generasi yang berilmu dan bertaqwa. Selain beribadah kepada allah, kita harus memiliki ilmu pengetahuan dan teknologi sebagai alat untuk memperoleh kesejahteraan hidup di dunia. Menurut M. arifin, sasaran pendidikan Islam adalah membina kesadaran atas diri manusia sendiri dan atas sistem sosial yang islami, sikap dan tanggung jawab sosialnya juga terhadap alam sekitar ciptaan allah serta kesadarannya untuk mengembangkan dan mengelola ciptaannya bagi kesejahteraan umum manusia. ${ }^{13}$

Ketiga, menjalin tali persaudaraan. Sebagaimana dalam firman-Nya, AlHujurat ayat 10:

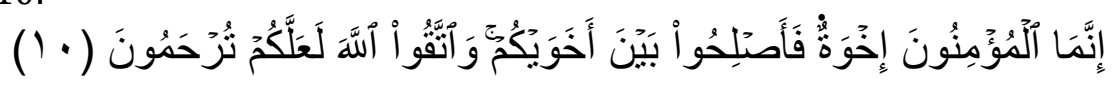

“Orang-orang beriman itu Sesungguhnya bersaudara. sebab itu damaikanlah (perbaikilah hubungan) antara kedua saudaramu itu dan takutlah terhadap Allah, supaya kamu mendapat rahmat."

Dari penjelasan tersebut, dapat dipahami bahwa kompetensi keagamaan merupakan integrasi secara kompleks antara pengetahuan agama, perasaan agama serta tindak keagamaan seseorang mahasiswa. Lebih dari itu, kompetensi keagamaan adalah kemampuan berpikir, bertindak dan bersikap dalam memahami dan mengamalkan ajaran Islam, baik yang berupa pengetahuan maupun amaliah sehingga menjadi pemeluk agama yang taat dan mampu mengajarkannya kepada orang lain.

Kompetensi keagamaan berfungsi untuk mempersiapkan mahasiswa dalam rangka memahami dan mengamalkan nilai-nilai ajaran agamanya sehingga menjadi ahli ilmu agama. Penguasaan kompetensi keagamaan bertujuan untuk membentuk mahasiswa yang memahami dan mengamalkan nilai-nilai ajaran agamanya sehingga menjadi ahli ilmu agama yang berwawasan luas, kritis, kreatif, inovatif dan dinamis dalam rangka mencerdaskan kehidupan bangsa yang beriman, bertakwa dan berakhlak mulia. ${ }^{14}$ Jenis-jenis kompetensi keagamaan, khususnya dalam Pendidikan Agama Islam terbagi menjadi empat, sebagaimana halnya aspek-aspek yang terbagi dalam pendidikan agama Islam.

13 Arifin, Ilmu Pendidikan Islam, 225-227.

${ }^{14}$ Undang-undang No. 55 Tahun 2007 Tentang Pendidikan Agama dan Pendidikan Keagamaan Bab III Pasal 8 ayat 1 dan 2. 
Jenis-jenis yang dimaksud meliputi al-Qur'ān, Aqidah-Akhlak, Fiqih dan SKI (Sejarah Kebudayaan Islam).

Pertama, al-Qur'ān-al-Hadith merupakan jenis kompetensi keagamaan yang memberikan pendidikan pada mahasiswa untuk memahami dan mencintai al-Qur'ān dan al-Ḥadith sebagai sumber ajaran Islam dan mengamalkan isi kandungannya dalam kehidipan sehari-hari. ${ }^{15}$ Kedua, Aqidah-Akhlak adalah kompetensi keagamaan yang bertujuan untuk menyiapkan mahasiswa untuk mengenal, memahami, menghayati dan mengimani Allah Swt sebagai dzat pencipta beserta makhluk-Nya sekaligus mengimplementasikannya dalam bentuk perbuatan mulia dalam kehidupan sehari-hari melalui kegiatan bimbingan, pengajaran, latihan, penggunaan pengalaman dan pembiasaan.

Ketiga, fiqih adalah salah satu jenis kompetensi keagamaan yang diarahkan untuk meyiapkan mahasiswa untuk mengenal, memahami, menghayati dan mengamalkan hukum Islam yang kemudian menjadi dasar pandangan hidupnya (way of life) melalui kegiatan bimbingan, pengajaran, latihan, penggunaan pengalaman, pembiasaan dan keteladanan. ${ }^{16}$ Keempat, sejarah kebudayaan Islam (SKI) adalah jenis kompetensi keagamaan yang menyiapkan mahasiswa untuk mengenal, memahami, dan menghayati sejarah kebudayaan Islam (SKI) yang kemudian menjadi dasar pandangan hidupnya (way of life) melalui kegiatan bimbingan, pengajaran, latihan, penggunaan pengalaman, pembiasaan dan keteladanan. ${ }^{17}$

Faktor-faktor yang mempengaruhi terbentuknya kompetensi keagamaan ada dua jenis faktor, yaitu: faktor internal dan faktor eksternal mahasiswa. Faktor internal terdiri dari intelegensi atau kecerdesan, sikap, bakat, minat, motivasi dan kematangan fisiologis dan psikologis mahasiswa. Sedangkan, faktor eksternal terdiri dari kondisi lingkungan sosial (keluarga, pendidikan dan masyarakat), kondisi lingkungan non-sosial (suhu, kelembapan udara, cuaca) dan instrumental (keras: kondisi gedung dan alat-alat praktikum dan lunak: kurikulum, tenaga pendidik dan tata tertib).

\section{Fungsi Evaluasi dalam Penerimaan Mahasiwa UIN Sunan Ampel Surabaya}

Evaluasi merupakan proses memberi pertimbangan mengenai nilai dari bahan atau metode-metode untuk tujuan tertentu. Dengan kemampuan evaluasi siswa diharapkan mampu membuat suatu pemikiran tentang suatu pernyataan,

\footnotetext{
15 Departemen Agama RI, Pedoman Khusus Al-Qur'an-Hadis (Jakarta: Dirjen Bagais, 2004), 4.

16 Departemen Agama RI, Pedoman Khusus Fiqih (Jakarta: Dirjen Bagais, 2004), 42.

17 Mudlofir, Aplikasi Pengembangan Kurikulum Tingkat Satuan Pendidikan dan Bahan Ajar dalam Pendidikan Islam, 50.
}

Jurnal Pendidikan Agama Islam (Journal of Islamic Education Studies)

Volume 5 Nomor 2 (2017)

ISSN(p) 2089-1946\& ISSN(e) 2527-4511

Hal. 252 - 263 
konsep, situasi dan sebagainya berdasarkan kriteria tertentu. ${ }^{18}$ Hal pokok yang perlu diperhatikan dalam evaluasi adalah menciptakan kondisinya sedemikian rupa sehingga siswa mengembangkan kriteria, standar atau ukuran untuk mengevaluasi sesuatu. Evaluasi dapat diklasifikasikan menjadi enam tipe seperti berikut: (1) Dapat memberikan evaluasi tentang ketepatan suatu karya atau dokumen; (2) Dapat memberikan evaluasi tentang keajegan dalam memberikan argumentasi, avidensi dan kesimpulannya, logika dan organisasinya; (3) Dapat memahami nilai serta sudut pandang yang dipakai orang dalam mengambil suatu keputusan; (4) Dapat mengevaluasi suatu karya dengan membandingkannya dengan karya lain yang relevan; (5) Dapat mengevaluasi suatu karya dengan mengukur criteria yang telah ditetapkan: (6) Dapat memberikan evaluasi suatu karya dengan mengukur sejumlah kriteria yang eksplisit.19

Evaluasi mempunyai kedudukan yang sangat strategis dan penting, karena hasil dari kegiatan evaluasi dapat dipergunakan sebagai input atau masukan untuk melakukan kegiatan perbaikan pendidikan. Begitu strategis dan penting, Islam juga menaruh perhatian yang besar terhadap evaluasi tersebut. Allah Swt dalam al-Qur'an memberitahukan kepada hamba-Nya bahwa pekerjaan evaluasi terhadap manusia terdidik merupakan suatu tugas penting dalam rangkaian proses pendidikan yang telah dilaksanakan oleh pendidik. Hal ini dapat dipahami dari ayat al-Qur'ān surat al-Baqarah ayat 31-33 sebagai berikut:

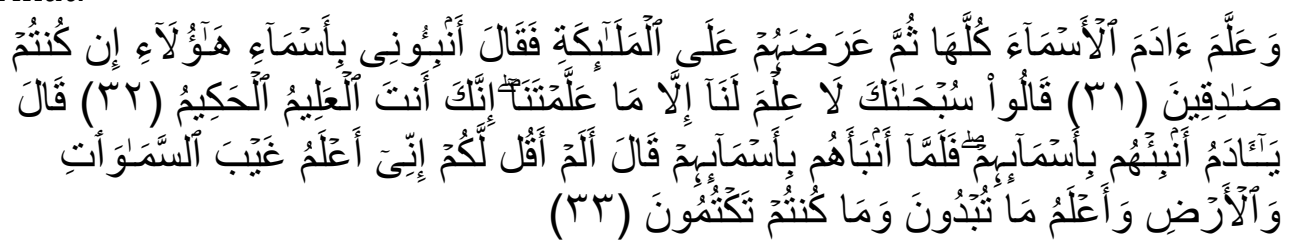

"Dan Dia mengajarkan kepada Adam nama-nama (benda-benda) seluruhnya, kemudian mengemukakannya kepada Para Malaikat lalu berfirman: "Sebutkanlah kepada-Ku nama benda-benda itu jika kamu mamang benar orangorang yang benar!". Mereka menjawab: "Maha suci Engkau, tidak ada yang Kami ketahui selain dari apa yang telah Engkau ajarkan kepada kami; Sesungguhnya Engkaulah yang Maha mengetahui lagi Maha Bijaksana." Allah berfirman: "Hai Adam, beritahukanlah kepada mereka nama-nama benda ini." Maka setelah diberitahukannya kepada mereka nama-nama benda itu, Allah berfirman: "Bukankah sudah Ku katakan kepadamu, bahwa Sesungguhnya aku mengetahui rahasia langit dan bumi dan mengetahui apa yang kamu lahirkan dan apa yang kamu sembunyikan?"20

18 Ngalim Purwanto, Prinsip dan Teknik Evaluasi Pengajaran (Bandung: Remaja Rosdakarya, 2002), 47.

${ }^{19}$ Purwanto, Prinsip dan Teknik Evaluasi Pengajaran, 47-48.

20 al-Qur'an. 2: 31-33 
Evaluasi adalah suatu proses yang sistematis dan berkelanjutan untuk menentukan kualitas (nilai dan arti) dari suatu aktivitas yang telah dilakukan berdasarkan pertimbangan dan kriteria (norma) tertentu, yang nantinya digunakan dalam rangka membuat suatu keputusan terhadap aktivitas yang telah dilakukan tersebut. ${ }^{21}$ Evaluasi berbeda dengan penilaian dan pengukuran. Evaluasi dan penilaian lebih bersifat komprehensif yang meliputi pengukuran, sedangkan pengukuran sendiri lebih bersifat kuantitatif (angka-angka) tentang kemajuan belajar peserta didik, sedangkan evaluasi dan penilaian lebih bersifat kualitatif. 22

Evaluasi memiliki banyak fungsi bergantung dari cara pandangan seseorang. Khusus dalam pendidikan, setidaknya evaluasi memiliki tujuh fungsi: pertama, fungsi psikologis; kedua, fungsi sosiologis; ketiga, penempatan; keempat, seleksi dan penentuan kesiapan belajar;kelima, diagnosa dosen untuk memperbaiki proses perkuliahan; keenam, sebagai administrasi dan ketujuh, penentuan kompetensi dan peningkatan motivasi belajar.

Berkaitan dengan fokus masalah yang diangkat, maka fungsi evaluasi berkenaan dengan diagnosa (diidentifikasi) kompetensi keagamaan mahasiswa PAI Fakultas Tarbiyah dan Keguruan UIN Sunan Ampel Surabaya. Input PAI berasal dari berbagai latar belakang jalur penerimaan mahasiswa. Tentunya hal tersebut meniscayakan perbedaan kompetensi keagamaan pada setiap mahasiswa berdasarkan masing-masing jalur penerimaan.

\section{Beberapa Jalur Penerimaan Mahasiswa di UIN Sunan Ampel Surabaya}

\section{Jalur SPAN-PTKIN}

SPAN-PTKIN merupakan pola seleksi prestasi akademik peserta didik yang dilaksanakan secara nasional oleh seluruh UIN/IAIN/STAIN dalam satu sistem yang terpadu dan diselenggarakan secara serentak oleh panitia pelaksana yang ditetapkan oleh menteri agama Republik Indonesia, yaitu direktorat pendidikan tinggi Islam kementerian agama Republik Indonesia. Biaya pelaksanaan SPAN-PTKIN ditanggung oleh pemerintah, sehingga peserta tidak dipungut biaya pendaftaran. ${ }^{23}$ Pelaksanaan SPAN-PTKIN secara nasional yang diikuti oleh seluruh PTKIN harus memenuhi prinsip adil,

21 Djemari Mardapi, Teknik Penyusunan Instrumen Tes dan Non Tes (Yogyakarta: Mitra Cendekia Press, 2008), 9.

22 Kusaeri, Acuan dan Teknik Penilaian dan Hasil Belajar dalam Kurikulum 2013 (Yogyakarta: Ar-Ruzz Media, 2014), 4-6.

23 Kementerian Agama RI, "Informasi dan Pendaftaran SPAN-PTKIN Tahun 2017", dalam http://span-ptkin.ac.id/informasi-pengumuman (12 Juli 2017), 1.

Jurnal Pendidikan Agama Islam (Journal of Islamic Education Studies)

Volume 5 Nomor 2 (2017)

ISSN(p) 2089-1946\& ISSN(e) 2527-4511

Hal. 254 - 263 
transparan dan tidak diskriminatif dengan tetap memperhatikan potensi calon mahasiswa dan kekhususan PTKIN.

Jalur SPAN-PTKIN ini merupakan jalur seleksi nasional yang hampir sama seperti jalur SNMPTN. Penerimaan mahasiswa baru melalui kedua jalur tersebut dilakukan berdasarkan hasil prestasi akademik dan prediksi dapat meyelesaikan studi di program studi yang dipilih. Bedanya, kalau SNMPTN berlaku untuk penerimaan calon mahasiswa baru di semua Perguruan Tinggi Negeri di Indonesia, sedangkan UM PTKIN berlaku untuk penerimaan calon mahasiswa baru masuk ke Perguruan Tinggi Keagamaan Islam Negeri di Indonesia.

Penyelenggaraan SPAN-PTKIN memiliki dua tujuan: Pertama, memberikan kesempatan dan kepercayaan kepada sekolah/madrasah agar mendaftarkan peserta didiknya melalui SPAN-PTKIN untuk memperoleh pendidikan tinggi di UIN/IAIN/STAIN. Kedua, mendapatkan calon mahasiswa baru yang berprestasi akademik tinggi melalui seleksi peserta didik SMA/SMK/MA/MAK/pesantren mu'adalah.24

2. Jalur UMPTKIN

UMPTKIN merupakan pola seleksi yang dilaksanakan secara nasional oleh seluruh Universitas Islam Negeri (UIN), Institut Agama Islam Negeri (IAIN) dan Sekolah Tinggi Agama Islam Negeri (STAIN) dalam sistem yang terpadu dan diselenggarakan secara serentak oleh panitia pelaksana yang ditetapkan oleh menteri agama republik Indonesia, yaitu direktorat pendidikan tinggi Islam kementerian agama Republik Indonesia. Pembiayaan penyelenggaraan UMPTKIN dibebankan kepada peserta seleksi dan kementerian agama Republik Indonesia. Bagi peserta yang lulus UMPTKIN dari keluarga pra-sejahtera yang memiliki prestasi akademik dan nonakademik dapat mengikuti seleksi program Bidik-Misi. ${ }^{25}$

Jalur UMPTKIN ini merupakan jalur seleksi nasional yang hampir sama seperti jalur SBMPTN. Penerimaan mahasiswa baru melalui kedua jalur tersebut dilakukan berdasarkan hasil ujian tertulis. Bedanya, jika SBMPTN berlaku untuk penerimaan calon mahasiswa baru di semua perguruan tinggi negeri di Indonesia, sedangkan UMPTKIN berlaku untuk penerimaan calon mahasiswa baru masuk ke perguruan tinggi keagamaan Islam negeri di Indonesia.

3. Jalur Mandiri UIN Sunan Ampel Surabaya

\footnotetext{
${ }^{24}$ Kementerian Agama RI, “Informasi dan Pendaftaran SPAN-PTKIN Tahun 2017”, 2.

25 Kementerian Agama RI, "Informasi dan Pendaftaran UM-PTKIN Tahun 2017", dalam http://www.um-ptkin.ac.id/home/informasi (12 Juli 2017), 1.
} 
Penerimaan mahasiswa baru jalur mandiri adalah sebuah sistem penyaringan dengan ujian yang diikuti oleh calom mahasiswa baru yang diselenggarakan oleh PTN terkait. Ujian ini diselenggarakan oleh pihak institusi dalam rangka memberikan alternatif pilihan bagi mereka yang tidak lolos tes SNMPTN/SPAN-PTKIN, SBMPTN/UMPTKIN untuk tetap dapat melanjutkan studi di Prodi yang tersedia di PTN yang dituju.

Terdapat perbedaan antara penerimaan mahasiswa baru jalur mandiri dengan SPAN-PTKIN dan UMPTKIN. Pertama, ditinjau dari pihak penyelenggara. Jalur mandiri diselenggarakan oleh masing-masing universitas yang tidak ada kaitannya dengan universitas lain. Kedua, ditinjau dari pilihan universitas yang dipilih. Jalur mandiri, pilihan universitasnya semakin sempit, yaitu satu universitas yang dituju saja. Akan tetapi, pilihan Prodinya bisa memilih dua sampai tiga Prodi yang berada di naungan universitas yang dituju. 26

\section{E. Perbandingan Kompetensi Keagamaan Antara Penerimaan Jalur SPAN, UM PTKIN dan Jalur Mandiri Tahun 2016 Mahasiswa Prodi PAI Fakultas Tarbiyah dan Keguruan UIN Sunan Ampel Surabaya}

Untuk menganalisis perbandingan kompetensi keagaamaan mahasiswa Prodi PAI Fakultas Tarbiyah dan Keguruan dilakukan dengen analisis deskripsi dan analisis rumus statistik one way anavadan $t$ test.

1. Analisis Deskriptif dengan Menggunakan Rumus Prosentase

Populasi penelitian, yaitu mahasiswa PAI angkatan tahun 2016 sebanyak 118 orang. Selanjutnya, penulis menentukan sampel dengan menggunakan rumus Slavin dengan taraf signifikansi $=5 \%(0,05)$ sehingga diperoleh sampel sebanyak 91 orang. Sampel sembilan puluh satu orang ini diambil secara acak (random sampling), dengan estimasi jalur SPAN-PTKIN diambil 30 orang, jalur UM PTKIN diambil 31 orang, dan jalurmandiri diambil 30 orang.

Kompetensi keagamaan yang akan dianalisis oleh penulis terdiri dari delapan jenis mata kuliah yang tersebar pada semester satu, yaitu mata kuliah Akhlak Tasawuf (AT), Akidah Ilmu Kalam (AIK), Fiqih Ibadah (Fiqih 1), Hadith Akhlak (HA), pengantar studi Islam (PSI), Sejarah Peradaban Islam (SPI), Studi Qur'an (SQ) dan Studi Hadith 1 (SH 1). Dari delapan mata kuliah tersebut, nilainya akan dijumlahkan guna mencari nilai rata-ratanya, dicari nilai tertinggi dan terendah pada masing-masing jalur penerimaan.

26 UIN Sunan Ampel, "Pendaftaran SPMB Online Mahasiswa UIN Sunan Ampel", dalam http://Pendaftaran Online UIN Sunan Ampel 2017_2018_PendaftaranOnline.Web.id 2017_2018.htm (12 Juli 2017), 1.

Jurnal Pendidikan Agama Islam (Journal of Islamic Education Studies)

Volume 5 Nomor 2 (2017)

ISSN(p) 2089-1946\& ISSN(e) 2527-4511

Hal. 256 - 263 
Analisis nilai terhadap delapan mata kuliah kompetensi keagamaan dari total 30 orang yang dijadikan sampel pada jalur penerimaan SPAN diperoleh nilai rata-rata sebesar 9,34 s/d 9,93 (mendapat nilai rata-rata As/d A). Mahasiswa pada jalur ini memperoleh nilai tertinggi pada mata kuliah Aakidah Ilmu Kalam dengan frekuensi dua puluh orang dengan prosentase $66,66 \%$. Selebihnya, sepuluh orang memperoleh nilai tertinggi pada mata kuliah yang berbeda, dengan estimasi tiga orang memperoleh nilai tertinggi pada mata kuliah Akhlak Tasawuf dengan prosentase 10\%, lima orang memperoleh nilai tertinggi pada mata kuliah Sejarah Peradaban Islam dengan prosentase $16,67 \%$ dan dua mahasiswa memperoleh nilai tertinggi pada mata kuliah Fiqih Ibadah (fFqih 1) dengan prosentase 6,67\%.

Nilai terendah pada jalur SPAN terletak pada mata kuliah Studi $\mathrm{H}$ \}adi>th 1 dengan frekuensi dua puluh empat mahasiswa dengan prosesntase $80 \%$. Selebihnya, enam mahasiswa memperoleh nilai terendah pada mata kuliah yang berbeda, dengan estimasi lima orang memperoleh nilai terendah pada mata kuliah studi qur'an dengan prosesntase $16,67 \%$ dan satu orang memperoleh nilai terendah pada mata kuliah Hadith Akhlak dengan prosentase 3,33\%.

Analisis nilai terhadap delapan mata kuliah kompetensi keagamaan dari total 31 orang yang dijadikan sampel pada jalur penerimaan UM PTKIN diperoleh nilai rata-rata sebesar 9,65 s/d 10,09 (mendapat nilai rata-rata As/d A). Mahasiswa pada jalur ini memperoleh nilai tertinggi pada mata kuliah akidah ilmu kalam dengan frekuensi dua puluh delapan orang dengan prosentase $90,32 \%$. Selebihnya, tiga orang memperoleh nilai tertinggi pada mata kuliah yang berbeda, dengan estimasi dua orang memperoleh nilai tertinggi pada mata kuliah Fiqih Ibadah (Fiqih 1) dengan prosentase 6,45\% dan satu orang memperoleh nilai tertinggi pada mata kuliah Akhlak Tasawuf dengan prosentase $3,23 \%$.

Nilai terendah pada jalur UM PTKIN terletak pada mata kuliah Studi Hadith 1 dengan frekuensi dua puluh sembilan mahasiswa dengan prosentase dengan prosentase 93,55\%. Selebihnya, dua orang memperoleh nilai terendah pada mata kuliah Hadith Akhlak dengan prosentase 6,45\%. Analisis nilai terhadap delapan mata kuliah kompetensi keagamaan dari total 30 orang yang dijadikan sampel pada jalur penerimaan UM PTKIN diperoleh nilai ratarata sebesar 9,28 s/d 10,06 (mendapat nilai rata-rata A- s/d A). Mahasiswa pada jalur ini memperoleh nilai tertinggi pada mata kuliah Fiqih Ibadah (Fiqih 1) dengan frekuensi dua puluh lima orang dengan prosentase 83,33\%. Selebihnya, lima orang memperoleh nilai tertinggi pada mata kuliah yang 
berbeda, dengan estimasi tiga orang memperoleh nilai tertinggi pada mata kuliah Akhlak Tasawuf dengan prosentase 10\% dan dua orang memperoleh nilai tertinggi pada mata kuliah Sejarah Peradaban Islam dengan prosentase $6,67 \%$.

2. Analisis Rumus Statistik One Way Anava terkait Perbandingan Kompetensi Keagamaan

Untuk mempermudah dalam menganalisis, dibuatlah tabel kerja, berikut ini:

Tabel Kerja One Way Anova

\begin{tabular}{|c|c|c|c|c|c|c|}
\hline No. & $\mathbf{S}$ & $\mathbf{U}$ & $\mathbf{M}$ & $\mathbf{S}^{\mathbf{2}}$ & $\mathbf{U}^{\mathbf{2}}$ & $\mathbf{M}^{\mathbf{2}}$ \\
\hline 1. & 9,59 & 9,65 & 9,5 & 91,9681 & 93,1225 & 90,25 \\
\hline 2. & 9,56 & 9,75 & 9,34 & 91,3936 & 95,0625 & 87,2356 \\
\hline 3. & 9,9 & 9,78 & 9,81 & 98,01 & 95,6484 & 96,2361 \\
\hline 4. & 9,53 & 10,06 & 9,5 & 90,8209 & 101,2036 & 90,25 \\
\hline 5. & 9,4 & 9,78 & 9,4 & 88,36 & 95,6484 & 88,36 \\
\hline 6. & 9,65 & 9,84 & 9,56 & 93,1225 & 96,8256 & 91,3936 \\
\hline 7. & 9,5 & 9,75 & 9,84 & 90,25 & 95,0625 & 96,8256 \\
\hline 8. & 9,5 & 9,81 & 9,31 & 90,25 & 96,2361 & 86,6761 \\
\hline 9. & 9,37 & 9,75 & 9,46 & 87,7969 & 95,0625 & 89,4916 \\
\hline 10. & 9,71 & 9,71 & 9,9 & 94,2841 & 94,2841 & 98,01 \\
\hline 11. & 9,71 & 9,87 & 9,37 & 94,2841 & 97,4169 & 87,7969 \\
\hline 12. & 9,34 & 9,84 & 9,53 & 87,2356 & 96,8256 & 90,8209 \\
\hline 13. & 9,71 & 9,78 & 9,71 & 94,2841 & 95,6484 & 94,2841 \\
\hline 14. & 9,65 & 9,75 & 9,34 & 93,1225 & 95,0625 & 87,2356 \\
\hline 15. & 9,71 & 9,96 & 9,84 & 94,2841 & 99,2016 & 96,8256 \\
\hline 16. & 9,93 & 9,65 & 9,46 & 98,6049 & 93,1225 & 89,4916 \\
\hline 17. & 9,71 & 9,81 & 10,06 & 94,2841 & 96,2361 & 101,2036 \\
\hline 18. & 9,84 & 9,71 & 9,5 & 96,8256 & 94,2841 & 90,25 \\
\hline 19. & 9,87 & 9,81 & 9,34 & 97,4169 & 96,2361 & 87,2356 \\
\hline 20. & 9,71 & 9,9 & 9,5 & 94,2841 & 98,01 & 90,25 \\
\hline 21. & 9,65 & 9,9 & 9,62 & 93,1225 & 98,01 & 92,5444 \\
\hline 22. & 9,71 & 10 & 9,68 & 94,2841 & 100 & 93,7024 \\
\hline 23. & 9,75 & 10,09 & 9,71 & 95,0625 & 101,8081 & 94,2841 \\
\hline 24. & 9,65 & 9,87 & 9,65 & 93,1225 & 97,4169 & 93,1225 \\
\hline 25. & 9,65 & 9,78 & 9,62 & 93,1225 & 95,6484 & 92,5444 \\
\hline 26. & 9,93 & 9,81 & 9,56 & 98,6049 & 96,2361 & 91,3936 \\
\hline
\end{tabular}

Jurnal Pendidikan Agama Islam (Journal of Islamic Education Studies)

Volume 5 Nomor 2 (2017)

ISSN(p) 2089-1946\& ISSN(e) 2527-4511

Hal. 258 - 263 
Kompetensi Keagamaan Mahasiswa Prodi PAI FTK UIN Sunan Ampel

\begin{tabular}{|c|c|c|c|c|c|c|}
\hline 27. & 9,78 & 9,87 & 9,31 & 95,6484 & 97,4169 & 86,6761 \\
\hline 28. & 9,93 & 9,71 & 9,28 & 98,6049 & 94,2841 & 86,1184 \\
\hline 29. & 9,81 & 10 & 9,34 & 96,2361 & 100 & 87,2356 \\
\hline 30. & 9,93 & 9,75 & 9,53 & 98,6049 & 95,0625 & 90,8209 \\
\hline 31. & - & 9,93 & - & - & 98,6049 & - \\
\hline Jumlah & 290,68 & 304,67 & 286,57 & 2817,295 & 2994,688 & 2738,565 \\
\hline Mean & 9,689333 & 9,828065 & 9,552333 & & - & \\
\hline Total & \multicolumn{5}{|c|}{881,92} & \multicolumn{3}{c|}{8550,548} \\
\hline
\end{tabular}

$$
\begin{array}{rr}
\text { SS }_{\text {tot }} \quad=\sum X \text { tot }^{2}-\frac{\left(\sum X\right)^{2}}{N} \\
=8550,548-\frac{(881,92)^{2}}{91} \\
=8550,548-\frac{777782,8864}{91} \\
=8550,548-8547,0646 \\
=3,4834 \\
\mathrm{SS}_{\text {tr }} \quad=\sum \frac{\left(\sum X_{k}\right)^{2}}{n}-\frac{\left(\sum X\right)^{2}}{N}
\end{array}
$$$$
=\frac{290,68^{2}+304,67^{2}+286,57^{2}}{31}-8547,0646
$$$$
=\frac{84494,8624+92823,8089+82122,3649}{31}-8547,0646
$$$$
=\frac{259441,0362}{31}-8547,0646
$$$$
=8369,0656-8547,0646
$$$$
=-177,999 \text { (diambil nilai positif) }
$$

$\mathrm{SS}_{\text {res }}=\mathrm{SS}_{\text {tot }}-\mathrm{SS}_{\text {tr }}$

$=3,4834-177,999$

$=-174,5156$ (diambil nilai positif)

$\mathrm{MS}_{\mathrm{tr}}=\frac{S S_{t r}}{k-1}$

$=\frac{177,999}{3-1}$

$=\frac{177,999}{2}$

$=88,999$

$$
\begin{aligned}
\text { MS }_{\text {res }}=\frac{S S_{\text {res }}}{N-k} \\
=\frac{174,5156}{91-3} \\
=\frac{174,5156}{88} \\
=1,983 \\
\mathrm{~F}=\frac{M S_{\text {tr }}}{M S_{\text {res }}} \\
=\frac{88,999}{1,983}
\end{aligned}
$$

Jurnal Pendidikan Agama Islam (Journal of Islamic Education Studies) 


$$
=44,88
$$

Menentukan nilai " $\mathrm{F}_{\text {tabel }}$ "

$\mathrm{F}=\frac{K-1}{N-k}$

$=\frac{3-1}{91-3}$

$=\frac{2}{88}$

$=\frac{V_{1}}{V_{2}}$

Melihat tabel harga distribusi " $F$ " dengan cara menentukan $V_{1}$ sebagai pembilang dan $V_{2}$ sebagai penyebut. Selajutnya, menentukan taraf signifikansi, yaitu 5\% atau 1\%. Selanjutnya, diperoleh $\mathrm{F}_{\text {tabel }}=3,44$ (nilai interpolasi/mendekati) apabila menggunakan taraf signifikansi $5 \%$ dan diperoleh $\mathrm{F}_{\text {tabel }}=4,88$ (nilai interpolasi/mendekati) apabila menggunakan taraf signifikansi $1 \%$.

Selanjutnya, merumuskan hipotesis deskriptif dan hipotesis statistik. Hipotesis deskriptif, yaitu Ha (ada perbedaan kompetensi keagamaan antara penerimaan jalur SPAN, UM PTKIN dan jalur mandiri tahun 2016 mahasiswa Prodi PAI fakultas Tarbiyah dan Keguruan UIN Sunan Ampel Surabaya) dan Ho (tidak ada kompetensi keagamaan antara penerimaan jalur SPAN, UM PTKIN dan jalur mandiri tahun 2016 mahasiswa Prodi PAI fakultas Tarbiyah dan Keguruan UIN Sunan Ampel Surabaya). Dari hal tersebut, kemudian ditentukan hipotesis statistiknya, Ha $\left(\mu_{\mathrm{A}} \neq \mu_{\mathrm{B}}\right.$ atau $\mu_{\mathrm{B}} \neq \mu_{\mathrm{C}}$ atau $\left.\mu_{\mathrm{A}} \neq \mu_{\mathrm{C}}\right)$ dan Ho $\left(\mu_{\mathrm{A}}=\mu_{\mathrm{B}}=\mu_{\mathrm{C}}\right)$. Pengujian hipotesis dapat dilakukan dengan dua kaidah. Pertama, apabila $\mathrm{F}_{\text {hitung }} \leq \mathrm{F}_{\text {tabel }}$ maka Ho diterima dan Ha ditolak. Kedua, apabila $\mathrm{F}_{\text {hitung }}>$ $F_{\text {tabel }}$ maka Ho ditolak dan Ha diterima.

Apabila diinterpretasi menggunakan taraf signifikasi 5\%, maka diperoleh $\quad F_{\text {hitung }}>F_{\text {tabel }}(44,88>3,44)$, dan apabila diinterpretasi menggunakan taraf signifikasi $1 \%$, maka diperoleh $F_{\text {hitung }}>F_{\text {tabel }}(44,88>4,88)$. Dengan demikian, dapat disimpulkan bahwa Ha diterima dan Ho ditolak, dengan kata lain "ada perbedaan kompetensi keagamaan antara penerimaan jalur SPAN, UM PTKIN dan jalur mandiri tahun 2016 mahasiswa Prodi PAI fakultas Tarbiyah dan Keguruan UIN Sunan Ampel Surabaya”.

Selanjutnya menguji signifikansi. Langkah pertama dalam melakukan uji signifikansi adalah menentukan kaidah pengujian. Kaidah pertama, apabila $t_{\text {hitung }}>t_{\text {tabel, }}$ maka signifikan. Kaidah kedua, apabila $t_{\text {hitung }} \leq t_{\text {tabel, }}$, maka tidak signifikan. Langkah kedua dalam melakukan uji signifikansi adalah menentukan nilai $t_{\text {tabel }}$ sebagai acuan interpretasi. Pertama, mencari nilai "dk" dengan perhitungan $\mathrm{df}=\mathrm{N}-\mathrm{nr}$. Sampel penelitian adalah 91 dan menggunakan 3 variabel, maka df $=91-3=88$. Apabila menggunakan taraf signifikansi 5\%, maka diperoleh nilai $t_{\text {tabel }}=1,665$ (nilai 
interpolasi/mendekati). Sedangkan, apabila menggunakan taraf signifikansi $1 \%$, maka diperoleh nilai $t_{\text {tabel }}=2,376$ (nilai interpolasi/mendekati).

Langkah ketiga adalah mencari nilai $t_{\text {hitung }}$ dengan menggunakan rumus uji " $\mathrm{t}$ ”. Berikut ini perhitungannya:

$$
\begin{aligned}
t_{\text {hitung }} & =r \sqrt{\frac{N-2}{1-r^{2}}} \\
& =44,88 \sqrt{\frac{91-2}{1-(44,88)^{2}}} \\
& =44,88 \sqrt{\frac{89}{1-2014,2144}} \\
& =44,88 \sqrt{\frac{89}{-2013,2144}} \\
& =44,88 \sqrt{-0,0442}
\end{aligned}
$$

Karena hasil akar kuadrat $-0,0442$ bernilai $-0,2102$ atau 0,2102 maka diambil nilai positifnya, yaitu 0,2102 . Selanjutnya:

$$
\begin{aligned}
& =44,88 \times 0,2102 \\
& =9,433
\end{aligned}
$$

Langkah terakhir adalah menginterpretasi nilai $t_{\text {hitung }}$ terhadap $t_{\text {tabel }}$. Dengan menggunakan taraf signifikansi 5\% yang bernilai 1,665 , maupun taraf signifikansi $1 \%$ yang bernilai 2,376, maka nilai $t_{\text {hitung }}>t_{\text {tabel, }}$ yaitu 9,433 > 1,665 dan 9,433 > 2.376. Dengan demikian, dapat disimpulkan bahwa perbedaan kompetensi keagamaan antara penerimaan jalur SPAN, SM-PTKIN dan jalur mandiri tahun 2016 mahasiswa Prodi PAI fakultas Tarbiyah dan Keguruan UIN Sunan Ampel Surabaya adalah "signifikan”.

\section{F. Kesimpulan}

Dari paparan tentang "Perbandingan Kompetensi Keagamaan antara penerimaan jalur SPAN, UM PTKIN dan jalur Mandiri tahun 2016 mahasiswa Prodi PAI fakultas Tarbiyah dan Keguruan UIN Sunan Ampel Surabaya", baik bersadarsarkan hasil analisis menggnakan prosentase, one way anavadan $t$ test maka dapat disimpulkan bahwa terdapat perbedaan yang signifikan pada masing-masing jalur penerimaan. Hasil tersebut berdasarkan analisis menggunakan one way anava dan uji T. Analisis perhitungan one way anava menghasilkan nilai $\mathrm{F}_{\text {hitung }}=44,88$. Apabila dikonfirmasi dengan nilai $\mathrm{F}_{\text {tabel, }}$ baik menggunakan taraf signifikansi $5 \%$ dan $1 \%$, maka $F_{\text {hitung }}>F_{\text {tabel }}(3,44<44,88>$ 4,88). Sedangkan, perhitungan uji $\mathrm{T}$ menghasilkan nilai $t_{\text {hitung }}=9,433$. Apabila dikonfirmasi dengan nilai $t_{\text {tabel, }}$ baik menggunakan taraf signifikansi $5 \%$ dan $1 \%$, maka $t_{\text {hitung }}>t_{\text {tabel }}(1,665<9,433>2,376)$. 
Adapun perbandingannya dapat dilihat dari persamaan dan perbedaan antara jalur SPAN, UM PTKIN dan Mandiri, sebagai berikut: Persamaan pertama, nilai rata-rata kompetensi keagamaan pada masing-masing jalur penerimaan terletak pada nilai A- s/d A $(9,18$ s/d 10,49), meskipun interval angka yang ditunjukkan pada masing-masing jalur penerimaan berbeda; SPAN-PTKIN berkisar antara 9,34 s/d 9,93, UM PTKIN berkisar antara 9,65 s/d 10,09 dan jalur mandiri berkisar antara 9,28 s/d 10,06. Persamaan kedua, terletak pada Studi Hadith sebagai mata kuliah keagamaan dengan nilai terendah pada masingmasing jalur penerimaan. Sedangkan, perbedaannya terletak pada mata kuliah keagamaan dengan nilai tertinggi. Mata kuliah keagamaan dengan nilai tertinggi pada jalur SPAN dan UM PTKIN ditempati oleh Aqidah Ilmu Kalam, mata kuliah keagamaan dengan nilai tertinggi sedangkan jalur Mandiri ditempati oleh Fiqih Ibadah (Fiqih 1).

\section{G. Referensi}

Arifin, M. Ilmu Pendidikan Islam. Jakarta: Bina Aksara, 1994.

Asy'arie, Musa. Agama, Kebudayaan Dalam Pembangunan Menyonsong Era Industrialisasi. Yogyakarta: IAIN Kalijaga Press, 1998.

Darajat, Zakiah. Ilmu Jiwa Agama. Jakarta: Bulan Bintang, 2005.

Departemen Agama RI. Pedoman Khusus Al-Qur'an-Hadis. Jakarta: Dirjen Bagais, 2004. . Pedoman Khusus Fiqih. Jakarta: Dirjen Bagais, 2004.

Dokumen bagian Akademik dan Kemahasiswaan FTK UIN Sunan Ampel Surabaya.

Hasyimi (al), Muhammad Ali. Sosok Pria Muslim. Bandung: Trigenda Karya, 1996.

Kementerian Agama RI. Standar Nasional Pendidikan Agama Islam. Jakarta: PAIS, 2011.

"Informasi dan Pendaftaran SPAN-PTKIN Tahun 2017", dalam http://span-ptkin.ac.id/informasi-pengumuman (12 Juli 2017).

Kusaeri. Acuan dan Teknik Penilaian dan Hasil Belajar dalam Kurikulum 2013. Yogyakarta: Ar-Ruzz Media, 2014.

Mardalis. Metode Penelitian: Suatu Pendekatan Proposal. Jakarta: Bumi Aksara, 1995.

Mardapi, Djemari. Teknik Penyusunan Instrumen Tes dan Non Tes. Yogyakarta: Mitra Cendekia Press, 2008.

Jurnal Pendidikan Agama Islam (Journal of Islamic Education Studies)

Volume 5 Nomor 2 (2017)

ISSN(p) 2089-1946\& ISSN(e) 2527-4511

Hal. 262 - 263 
Kompetensi Keagamaan Mahasiswa Prodi PAI FTK UIN Sunan Ampel

Mudlofir, Ali. Aplikasi Pengembangan Kurikulum Tingkat Satuan Pendidikan dan Bahan Ajar dalam Pendidikan Islam. Jakarta: Rajawali Pers, 2011.

Purwanto, Ngalim. Prinsip dan Teknik Evaluasi Pengajaran. Bandung: Remaja Rosdakarya, 2002.

Sagala, Syaiful. Kemampuan Profesional Guru dan Tenaga Kependidikan. Bandung: Alfabeta, 2011.

UIN Sunan Ampel, "Pendaftaran SPMB Online Mahasiswa UIN Sunan Ampel”, dalam http://Pendaftaran Online UIN Sunan Ampel 2017_2018_PendaftaranOnline.Web.id 2017_2018.htm (12 Juli 2017).

Undang-undang No. 55 Tahun 2007 Tentang Pendidikan Agama dan Pendidikan Keagamaan Bab III Pasal 8 ayat 1 dan 2.

Yusuf, Choirul Fuad. Inovasi Pendidikan Agama dan Keagamaan. Jakarta: Kemenag RI, 2006. 